\section{Nuclear waste}

\section{Dump it here, please}

THE British nuclear waste disposal agency, NIREX, is facing vocal opposition almost everywhere in Britain to its search for a new low and intermediate level disposal site. But its French equivalent, ANDRA, has had ten enquiries from the mayors of villages in central France inviting it to put its next site in their backyard.

The only problem is that although the French mayors are keen, for reasons of local development and employment, many of their people are not - for fear of the waste. Thus at one site, the village of Neuvy-le-roi near Tours on the Loire, the mayor was strongly in favour of ANDRA disposing low and intermediate level waste in the clay subsoil nearby, but his 1,000 villagers mounted a campaign against him. The mayor called a referendum: 63 per cent said no, and ANDRA has now dropped Neuvy-le-roi from its list.

However, still on the ANDRA list is Cholet, a town of 60,000 inhabitants south of Nantes and Angers, also near the Loire. Here the mayor is described as "very active" in attracting industry and employment, and the opposition is milder. "The behaviour at Cholet is very different from Neuvy-le-roi"' said an ANDRA spokesman. The opponents there "are people you can argue with".

One of the arguments is money. The French government, unlike the British, offers local authorities concerned with potential nuclear sites both cash incentives and cut-price electricity. Thus Cholet stands to gain FF 30 million ( $£ 3$ million) as a gift for housing and road improvements, and up to FF 1.5 million $(£ 150,000)$ a year off local electricity bills, if ANDRA chooses it as a disposal site.

In Britain, however, the one named site - at Elstow near Bedford north of London - has met enormous opposition. Bedfordshire County Council has declared the area a "nuclear free zone" and written to the Secretary of State for the Environment, Patrick Jenkin, in strong terms, claiming Elstow "totally unsuitable as a site for a nuclear waste repository". Tempers rose further when the British government decided to allow NIREX to investigate the site by means of a "special development order" - a stratagem which avoids the need for a public inquiry.

The reaction to this British stick was perhaps predictable. The French style, offering a carrot, might have worked better, according to a study made for NIREX by Professor Terrence Lee of the University of Surrey. His survey figures show that 48 per cent of Britons would like monetary compensation (but paid to individuals rather than the council) for the building of a nuclear waste repository nearby, and a further 36 per cent would like compensation paid to the council for community benefit or some similar support - making a total of 84 per cent who say they could be bought off.

Robert Walgate.

\title{
Maritime museum plan scuttled
}

THE Vityaz, formerly the pride of the Soviet research fleet, which completed her last voyage in April 1979, is now anchored, a near-derelict with peeling paint and rotting woodwork, off Kaliningrad, Pravda reported recently. Plans to turn her into a floating museum have become bogged down in bureaucracy despite backing from ministerial and state bodies.

Vityaz, launched in April 1949, and the third Soviet vessel of her name (meaning "hero" or "champion"), spent most of her working life in the Pacific, carrying geological, ichthyological and meteorological expeditions. Her last, 65th voyage, however, ended with a triumphal tour of the major maritime states, including Italy, France, Spain, Portugal, the United Kingdom and Denmark, before she finally dropped anchor in Kaliningrad. It was originally hoped that the ship could go by canal to Moscow and a future as a museum. In the end, however, it was decided to leave her in Kaliningrad, the major fishing and commercial port of the Soviet Baltic coast. There was talk of a "Museum of the World Ocean" in the centre of the city, on the banks of the canal, with Vityaz as the prime exhibit.
But then, in the words of Pravda, "it all turned out strangely". Vityaz, which had successfully weathered hundreds of thousands of miles of ocean voyaging, somehow became stuck fast when it came to completing the last few metres to her final berth. Now, almost six years after the Vityaz dropped anchor in Kaliningrad, only about half the money needed even for the minimum cosmetic refit is available in Kaliningrad. Money has, however, been spent on other things. A special harbour wall for the "memorial ship" has been erected, two smallish pre-war buildings have been renovated for the planned museum, and the surrounding terrain has been artistically laid out. According to the regional Communist Party secretaries, Yu Malakin and P. Kaz'min, public opinion in Kaliningrad still supports the idea of the ship museum, but someone has to make the official decision to build the museum complex. Once it is built, says $\mathrm{Mr} \mathbf{A}$. Shkurko, Deputy Minister of Culture of the Russian SFSR, his ministry will be delighted to take it over as a branch of the provincial museum of local history. No one, however, seems willing to assume responsibility for the decision to build.
Indian science

\section{Gandhi backs research}

New Delhi

THE government headed by Rajiv Gandhi, who has pledged to prepare India for the twenty-first century, has allocated the equivalent in rupees of $£ 900$ million, or about six per cent of the government's budget for 1985-86, for scientific research and development.

The allocation for science represents only a marginal increase over that for the previous year but it is significant for its emphasis on research and development in nonconventional energy sources, biotechnology, high-power lasers and thermonuclear fusion.

As in earlier years, the lion's share of the budget goes to the Department of Atomic Energy (DAE), which is to set up a new centre for advanced technology at Indore, in Madhya Pradesh. Besides housing a new facility for plasma research, the centre will develop lasers for isotope separation and high power niodymium-glass lasers for laser-induced fusion. DAE also intends to set up a synchrotron radiation source, build superconducting magnets for its heavy-ion

Budget allocations by sector ( $£$ million)

Department of Atomic Energy $\quad £ 210.0$ Space

133.0

Industrial research

114.4

Defence research

104.0

Non-conventional energy

65.0

Agricultural research

Electronics

55.5

Oceanography

78.0

Meteorology

20.7

Other

93.0

Total 900.6

accelerator and establish a medical cyclotron for producing short-lived positron-emitting isotopes and radioactively labelled pharmaceutical preparations.

The Department of Ocean Development (DOD), which has assessed India's ocean thermal energy conversion (OTEC) potential at $50,000 \mathrm{MW}$, is planning to begin work this year on a 1-MW OTEC plant on the island of Lakshadweep. DOD will also place an order for an ice-breaker, estimated to cost $£ 30$ million, for undertaking expeditions to Antarctica. Previous expeditions were made in vessels chartered from Norway.

Electronics and biotechnology have been singled out as frontier areas. The government has abolished excise duty on computers and drastically reduced customs duty on their import. The Department of Electronics will launch this year a project to design a "fifth generation superminicomputer incorporating inference and knowledge based management functions". The Ministry of Science and Technology has earmarked a sum of $£ 5$ million for a biotechnology centre in New Delhi, its con- 